Article

\title{
Entomopathogenic Fungi Associated with Exotic Invasive Insect Pests in Northeastern Forests of the USA
}

\author{
Vladimir Gouli ${ }^{1}$, Svetlana Gouli ${ }^{1}$, José A. P. Marcelino ${ }^{2,}{ }^{*}$, Margaret Skinner ${ }^{1}$ and
} Bruce L. Parker ${ }^{1}$

1 Entomology Research Laboratory, University of Vermont, 661 Spear Street, Burlington, VT 05405, USA; E-Mails: vgouli@uvm.edu (V.G.); sgouli@uvm.edu (S.G.); mskinner@uvm.edu (M.S.); bparker@uvm.edu (B.L.P.)

2 Azorean Biodiversity Group (GBA, CITA-A) and Portuguese Platform for Enhancing Ecological Research and Sustainability (PEERS), University of the Azores, 9500-321, Portugal

* Author to whom correspondence should be addressed; E-Mail: jmar06@gmail.com.

Received: 28 August 2013; in revised form: 16 October 2013 / Accepted: 23 October 2013 /

Published: 4 November 2013

\begin{abstract}
Mycopathogens of economically important exotic invasive insects in forests of northeastern USA have been the subject of research at the Entomology Research Laboratory, University of Vermont, for the last 20 years. Elongate hemlock scale, European fruit lecanium, hemlock woolly adelgid and pear thrips were analyzed for the presence of mycopathogens, in order to consider the potential for managing these pests with biological control. Fungal cultures isolated from insects with signs of fungal infection were identified based on morphological characters and DNA profiling. Mycopathogens recovered from infected insects were subdivided into three groups, i.e., specialized entomopathogenic; facultative entomopathogens; ubiquitous opportunistic contaminants. Epizootics were caused by fungi in the specialized group with the exception of $M$. microspora, $P$. marquandii and I. farinosa. Inoculation of insects in laboratory and field conditions with B. bassiana, L. muscarium and Myriangium sp. caused insect mortality of 45 to $95 \%$. Although pest populations in the field seemed severely compromised after treatment, the remnant populations re-established themselves after the winter. Although capable of inducing high mortality, a single localized aerial application of a soil-dwelling fungus does not maintain long-time suppression of pests. However, it can halt their range expansion and maintain populations below the economic threshold level without the use of expensive insecticides which have a negative impact on the environment.
\end{abstract}


Keywords: entomopathogenic fungi; Myriangium duriaei; Hirsutella lecaniicola; Beauveria bassiana; Colletotrichum fioriniae; Lecanicillium muscarium; Paecilomyces marquandii; Metarhiziopsis microspora; piercing-sucking insects; Fiorinia externa; Parthenolecanium corni; Adelges tsugae; Taeniothrips inconsequens

\section{Introduction}

Globalization is expanding the established geographical and historical range of many living organisms. Unpremeditated migration of exotic species to North America started with the first settlers from Europe and Asia. Numerous species of microorganisms, plants and animals have adapted to the different climatic zones of Canada, USA and Mexico. As a rule, exotic species create the most severe economic problems because local biota are not adapted to counteract these new immigrants. Agricultural, forest and ornamental plants in North America are severely damaged by many exotic phytophagous species.

Species with piercing and sucking mouthparts, especially armored scales, adelgids and thrips, have a significant economic impact. In the northeastern region of the USA, widespread defoliation of sugar maple trees periodically occurs as a result of the activity of the exotic pear thrips, Taeniothrips inconsequens (Uzel) [1]. This pest was initially identified causing damage to maples in Pennsylvania in 1979, and Vermont in 1985 [2]. In 1988, feeding damage caused by pear thrips contributed to defoliation of over 200,000 hectares in Vermont [3], 400,000 in Pennsylvania [1] and 81,000 hectares in Massachusetts [4]. Other northeastern states, including New York, Connecticut and New Hampshire, were also affected [5]. The complex of exotic invasive species, including hemlock woolly adelgid (HWA), Adelges tsugae Annand (Hemiptera: Adelgidae); and elongate hemlock scale (EHS), Fiorinia externa Ferris (Hemiptera: Diaspididae), threaten the very existence of hemlock trees. Hemlock woolly adelgid has become the principal pest of eastern hemlock, Tsuga canadiensis and Carolina hemlock, T. carolineana. It may also become a significant pest of other coniferous trees [6]. The European fruit lecanium scale (LS), Parthenolecanium corni Bouche (Hemiptera: Coccidae), also intermittently causes significant damage to a wide variety of forest trees and other agricultural and ornamental plants. The morphological and biological characteristics of thrips, adelgids and scales, together with their high reproductive potential and cold-resistance, facilitate their successful colonization and establishment in vast areas of North America. Application of broad spectrum chemical pesticides is not advised for forests, because of the negative environmental implications, and their inability to provide long term solutions to pest problems. However, the urgency of plant protection often requires their use. The development of alternative strategies to chemical pesticides is urgent. Research activity on alternative management strategies for hemlock woolly adelgid and other exotic invasives has increased since the mid-1990s [7]. Several entomophagous insects including Laricobius nigrinus, Scymnus camptodromus, S. ningshanensis, S. sinuanodulus, and Sasajiscymnus tsugae (Coleoptera: Coccinellidae) were discovered in China and Japan and have been imported as possible biological control agents against hemlock woolly adelgid in the USA, and some have been successfully established. Scymnus tsugae, which was released in Connecticut and Virginia in 1997, reduced hemlock woolly adelgid densities by $47 \%-83 \%$ [8]. 
Another biological control strategy against invasive insect pests is the use of entomopathogenic fungi. Special attention has been given to entomopathogenic fungal research because they have the ability to penetrate through the insect's cuticle. A significant research initiative began in the 1990s in Vermont directed towards development of entomopathogenic fungi for exotic insects impacting forest health, including pear thrips, hemlock woolly adelgid, elongate hemlock scale, and European fruit lecanium scale. Numerous fungal isolates including Lecanicillium lecanii, Hirsutella spp., Beauveria bassiana, Metarhizium anisopliae, Mariannaea sp. and others have been recovered from infected pear thrips $[9,10]$. Other fungal isolates have been found to be associated with elongate hemlock scale and lecanium scale [11-14]. These entomopathogenic agents offer an opportunity for biological regulation of exotic invasive species, especially when the fungal pathogens are found associated with epizootic processes, where a rapid decline of the pest population is occurring [15]. The humid climate of the northeastern USA favors manifestation of fungal epizootics such as the one observed among populations of gypsy moth, Lymantria dispar, which is caused by the entomophthoralean fungus Entomophthora maimaiga [16]. In May 2006, the Vermont Department of Forests, Parks and Recreation issued a warning that forest tent caterpillar, Malacosoma disstria, was forecasted to cause widespread defoliation of 165,000 hectares of forest land., However, in a short period of time, an epizootic caused by the fungus, Furia gastropachae, led to the rapid decline of populations and halted the development of the predicted scenario of deforestation. Explosive epizootics are often connected with the activity of entomophthoralean fungi, namely in arthropods with piercing and sucking mouthparts, especially mites [17-19] and aphids [20-22].

Currently thousands of fungal species and strains have been isolated and identified from a vast number of arthropod species around the globe [23]. However, our knowledge of the activity of fungi in natural insect populations and the possibility to apply them for pest control management strategies is limited. This article discusses empirical research on the potential of entomopathogenic and entomophilous fungi as biocontrol agents within populations of exotic invasive insects of the northeastern forests of the USA In addition, it provides standardized sampling protocols, as well as in vitro and in situ fungal isolation \& insecticidal activity protocols. Illustrations of the most common signs and symptoms of disease, found associated with insect epizootics in forest stands of the northeastern USA, are reported. These standardized protocols and illustrations can prove to be an expedient tool to isolate and identify epizootic pathogens in situ and in vitro. The standardized methodologies reported here were developed by scientists and students at the Entomology Research Laboratory, University of Vermont over the last 20 years.

\section{Experiment}

\subsection{Standardized Insect Sampling Protocols}

Pathogens of forest insects were collected from populations of elongate hemlock scale, European fruit lecanium scale, hemlock woolly adelgid, and pear thrips over the last 20 years of research at the Entomology Research Laboratory (ERL, Burlington, VT, USA).

Symptomatic insects were collected from Vermont, New Hampshire, Massachusetts, New York, and Rhode Island. Pathological material was also collected during routine monitoring activities and 
numerous surveys in forest stands. Insects with signs of mycoses were also obtained from collectors at universities, forest specialists and members of the general public. In addition, in order to sample for entomopathogenic fungi of hemlock woolly adelgid and elongate hemlock scale, the ERL established six forest sites, located in New Hampshire, Massachusetts, Rhode Island and New York, for the long term monitoring of pathogens of insect pests (1997-2013). These sites were selected where mass insect mortality was observed. In each of the six sample sites, 10 co-dominant eastern hemlock trees with symptomatic insects were selected at random (total 60 trees). As a rule, all surveys were carried on twig samples of approximately $10 \mathrm{~cm}$ long with hemlock woolly adelgid and/or elongate hemlock scale were clipped from each tree and processed within 48 hours of collection to isolate fungi. Periodically, biological material from northeastern states was obtained via the United States Department of Agriculture (USDA) Forest Service personnel.

For collection of entomopathogenic fungi from pear thrips - an insect that spends $10 \mathrm{month} /$ year in the soil-samples were collected on sites located in three geographically distinct areas, corresponding to three USDA plant cold hardiness zones (3, 4, and 5). Within each area, two forest stands predominating in sugar maple were identified (each $\sim 10$ hectares) and long term sites were established. These were selected because sugar maple trees (Acer spp.), exploited for maple syrup production, represent an important economic activity in some New England states, and their protection is of particular interest. Samples were taken over time (1999-2012) in two types of Vermont forests, those with $90 \%$ and those with $75 \%$ sugar maple trees in the overstory. This permitted an assessment of fungal biodiversity within different forest types over time. The standard methodology for these surveys, within each maple stand, consisted of four plots randomly established 100-200 m apart. At each randomly established plot center, five nearby dominant sugar maple trees were selected. At each tree one soil sample was taken $0.5 \mathrm{~m}$ from the bole and one a few $\mathrm{cm}$ inside the drip line of the tree using a standard tulip bulb planter. Samples were collected between September and November before the soil froze. Each soil sample was placed in a cylindrical container $(10 \times 13 \mathrm{~cm})$ and the top covered with a piece of 4-mil transparent plastic sheet, coated on one side with a thin film of Tanglefoot ${ }^{\circledR}$ to catch thrips as they emerged from the soil. Containers with soil samples were kept at room temperature $\left(22{ }^{\circ} \mathrm{C} \pm 2{ }^{\circ} \mathrm{C}\right.$ ) for 35 days, after which the sticky lids were removed and inspected at $40 \times$. Pear thrips and other arthropods were removed and used for pathological analyses and subsequent isolation of fungi.

Entomopathogenic fungi were also isolated from heavy infestation of European lecanium scale sampled from maple saplings (2007-2010). The standard methodology for these surveys and fungal isolation protocols consisted of five sugar maple trees, selected at random, and from each tree, five twigs, approximately 20-30 cm long and infested with lecanium scale were collected and placed in separate plastic bags. Twigs were inspected microscopically, and scales with obvious signs of fungal infection (i.e., fungal mycelia covering partially or completely the body of the insect) were removed and handled as described below in order to retrieve fungal mycoses.

\subsection{Pathological Analyses and Isolation of Fungi Protocols}

Diseased insects or fresh cadavers were used to prepare slides. Two methods were used: (a) insects were placed individually on slides in a mixture of glycerol and saline solution (1:1 volume) [24] and covered with a cover slip; (b) scotch tape imprint method. The tape method was as follows: insects 
were placed between two pieces of tape and gently squashed. The two tapes were separated, and each was placed in a droplet of cotton blue stain to detect fungal propagules or other microorganisms in the insect's body [25]. We found this method allowed for efficient discernment of microorganisms in and on the insect host surface.

Slides were examined using light and phase contrast microcopy, to accurately detect morphological peculiarities of insect tissues and the presence of fungal propagules. Pathological structures were documented by preparation of micrographs.

Two protocols were commonly used over the years to isolate fungi from infected insects. In a first protocol, insects were surface sterilized by dipping them for $1 \mathrm{~min}$. in a solution of $2.5 \%$ sodium hypochlorite with $0.08 \%$ Silvet L-7 $7^{\circledR}$ (polysiloxane polyether copolymer), then rinsing them twice with sterile distilled water (SDW) and plating them on three different growth media, i.e., potato dextrose agar (PDA) supplemented with penicillin $(0.02 \mathrm{~g} / \mathrm{L})$ and streptomycin $(0.04 \mathrm{~g} / \mathrm{L})$, Sabouraud dextrose agar and yeast (SDAY), and an experimental composition based on medium for cultivation of insect cells (TC-100, Sigma, St. Louis, MT, USA) with the addition of raw egg yolk (10\%). For the second protocol, diseased insects or cadavers were homogenized in two ml sterile distilled water (SDW), after surface sterilization, and then the homogenate mixture was diluted 1:10 with SDW. Initial and diluted homogenate mixtures were used for inoculation of the three different media described above. Inoculated Petri dishes were incubated for 3 weeks at $24{ }^{\circ} \mathrm{C}$. Single fungal colonies were transferred to new Petri dishes each week. Isolates were purified using standard dilution techniques [26].

\subsection{Protocols for the Identification of Fungi}

Fungal cultures were identified based on morphological characteristics and DNA analyses. Common saprophytic species were excluded from further research. These included species from the genera Penicillium, Cladosporium, Mucor and some others. Identification based on morphological and cultivation characteristics was done using taxonomic guidelines and fungal fruiting bodies [27-30]. Fungal specimens were also sent to specialists for verification of identification when necessary. Some isolates were then identified based on DNA analyses following methodologies described in Marcelino et al. [13]. Genes commonly used for phylogenetic analysis at the generic level and above (i.e., 28S ribosomal DNA) were selected, as well as genes for within-species differentiation (i.e., the internal transcribed spacers, ITS).

\subsection{Protocols for the Estimation of Insecticidal Activity of Fungi (in Vitro and in Situ).}

Several of the isolates collected over the last 20 years were assessed for pathogenicity aganist hemlock woolly adelgid and elongate hemlock scale under laboratory and field conditions. Hemlock twigs (15 cm long) infested with hemlock woolly adelgid and/or elongate hemlock scale (50 target insects/branches) were collected in the field. Standard protocols for insecticidal activity of fungi were as follows: first, each twig was put in a glass tube with wet sand to prevent dessication. Subsequently, the twigs were sprayed with a suspension of fungal conidia at $5 \times 10^{7}$ conidia/mL suspended in sterile distilled water (SDW) with $0.02 \%$ Silwet (Momentive, Columbus, OH, USA). When a complex of fungi was isolated from diseased or dead insects (e.g., Myriangium duriaei \& Colletotrichum fioriniae; 
Lacanicillum lecanii \& Beauveria bassiana), these were both suspended in $5 \times 10^{7}$ conidia/mL concentrations in one single solution. A $0.02 \%$ solution of Silwet with SDW was used for blank control treatments. The twigs were held vertically in a rack and individually sprayed with a hand-held atomizer at a distance of $30 \mathrm{~cm}$ with $200 \mu \mathrm{L}$ of the treatment solution. Twigs were individually placed in sterile graduated $50 \mathrm{~mL}$ conical tubes containing $16 \mathrm{~g}$ of sterilized sand and $7 \mathrm{~mL}$ sterile distilled water. Each tube was partially covered with a cap to allow ventilation. The tubes were placed in a plastic bag to maintain controlled environmental conditions $\left(22{ }^{\circ} \mathrm{C}\right.$ with $\left.16: 8 \mathrm{LD}\right)$. The twigs were inspected after 3, 5 and 7 days to determine the number of live and dead insects, from which the percent mortality was determined. Morphological changes in the cuticle or body of cadavers, specifically changes in color or body turgor, were used to determine if the insect was dead. Each bioassay was repeated three times with four replicates for each treatment. Isolates showing the greatest potential in terms of pathogenicity were further tested by spraying a similar suspension on infested branches in a forest setting. Branches for treatment were selected based on visual inspection to ensure they contained at least 50 target insects/branches. Samples were taken before treatment, immediately after treatment and at several days after treatment and assessed for mortality. To further confirm the pathogenicity of the isolates, a random sample of dead insects (10 individuals/twig) were selected and plated to isolate fungi. Subsequently, pathological analyses and isolation of fungi was made, as described above.

\section{Results and Discussion}

Local epizootics were consistently found in correlation to the activity of fungi in each of the populations of elongate hemlock scale (EHS), hemlock woolly adelgid (HWA) and pear thrips investigated (Tables 1 and 2). Metarhiziopsis microspora epizootics did not have a significant impact on insect mortality. This was also the case for the fungi Paecilomyces marquandii and Isaria farinosa (data not shown). The complex of $M$. duriaei \& $C$. fioriniae caused EHS mortality rates from $27 \%-67 \%$, depending on locality (Table 1). Natural mycoses in HWA were particularly found in association with the facultative entomopathogen Phoma spp. (Table 1). A wide range of mortality rates were observed depending on locality, but never bellow 20\%. Subsequent experimental inoculation of HWA and EHS under laboratory and field conditions using the entomopathogens B. bassiana, L. muscarium and Myriangium sp., retrieved from EHS epizootics, resulted in higher insect mortality, up to $95 \%$ [12,31-33].

Mycoses on EHS, associated with Myriangium duriaei, were characterized by the formation of black sclerotized masses on the scale surface. Infected scales survived after initial infection. The early mycelial biomass on EHS was typically white and progressed to brown and finally black (Figure 1). M. duriaei recovered from infected elongate hemlock scale was characterized by slow growth on all media. Typical colonies had curled margins and umbonate elevations. The fungus developed as a massive septate vacuolated mycelium which formed chlamydospores (Figure 2); eventually, the mycelium dehydrated, hardened and accumulated melanin (Figure 1). Crawlers (i.e., the 1st mobile instar) often did not reach adulthood and the ones that reached adulthood, or imagos, developed more slowly than the control populations in uncontaminated twigs. However, females with visible signs of fungal infection were still able to produce a new generation of crawlers (Figure 3). This first type of 
elongate hemlock scale mycosis was complex due to the recurrent presence of another fungus with M. duriaei, initially identified as the phytopathogen Colletotrichum acutatum. The fungus caused disease in experimental inoculations of elongate hemlock scale and Koch's postulates were positive. The fungus was subsequently described as a new entomopathogenic subspecies, C. acutatum var. fioriniae [13], and re-assessed as a new species C. fioriniae (Marcelino \& Gouli) R.G. Shivas \& Y.P. Tan [34]. Biological properties of this fungus have been described [13,14,35]. The second type of mycosis is characterized by the formation of white rounded fungal structures around the scales (Figure 4). These formations are described as sporodochia, and represent an accumulation of short conidiophores with phialides. Fungal isolates obtained from scales with this second type of mycosis were initially identified based on DNA analysis as Cordyceps sp. [14] and subsequently described as a new species, Metarhiziopsis microspora [36].

Table 1. Natural occurring mycoses in elongate hemlock scale and hemlock wooly adelgid populations on $25-30 \mathrm{~cm}$ long twigs.

\begin{tabular}{|c|c|c|c|c|}
\hline \multicolumn{5}{|c|}{ Mycoses in elongate hemlock scale (EHS) } \\
\hline Location & $\begin{array}{l}\text { Total number of twig } \\
\text { samples investigated }\end{array}$ & $\begin{array}{l}\text { Fungi isolated from dead } \\
\text { and diseased insects }\end{array}$ & Mortality, \% & $\begin{array}{c}\text { Date of } \\
\text { collection }\end{array}$ \\
\hline Bayberry Lane $^{a}$ & 100 & $\begin{array}{l}\text { Myriangium duriaei \& } \\
\text { Colletotrichum fioriniae }\end{array}$ & $35-67$ & Jun. 2006 \\
\hline Litchfield $^{\mathrm{b}}$ & 100 & $\begin{array}{l}\text { Myriangium duriaei \& } \\
\text { Colletotrichum fioriniae }\end{array}$ & $27-45$ & Jun. 2006 \\
\hline $\begin{array}{l}\text { Mount Tom Forest } \\
\text { Reserve }^{c}\end{array}$ & 100 & $\begin{array}{c}\text { Lecanicillium lecanii \& } \\
\text { Beauveria bassiana }\end{array}$ & $\begin{array}{l}1-2 \\
1-2\end{array}$ & Jun. 2005 \\
\hline Valley Forge ${ }^{\mathrm{d}}$ & 200 & Metarhiziopsis microspora & $0.1-2.0$ & Jul. 2005 \\
\hline \multicolumn{5}{|c|}{ Mycoses in hemlock woolly adelgid (HWA) } \\
\hline Location & $\begin{array}{l}\text { Total number of twig } \\
\text { samples investigated }\end{array}$ & $\begin{array}{l}\text { Fungi isolated from dead } \\
\text { and diseased insects }\end{array}$ & Mortality, \% & $\begin{array}{c}\text { Date of } \\
\text { collection }\end{array}$ \\
\hline $\begin{array}{l}\text { Vaughan Woods } \\
\text { State Park }\end{array}$ & 47 & Phoma sp. & $71-92$ & Nov. 2011 \\
\hline Kittery ${ }^{\mathrm{e}}$ & 40 & Phoma sp. & $50-81$ & Nov. 2011 \\
\hline York $^{\mathrm{e}}$ & 40 & Phoma sp. & $53-89$ & Nov. 2011 \\
\hline Harriman State Park ${ }^{\mathrm{a}}$ & 12 & Myriangium sp. & $22-40$ & Oct. 2011 \\
\hline Love Lane ${ }^{f}$ & 5 & Phoma sp. & $50-80$ & Aug. 2011 \\
\hline King Brook ${ }^{f}$ & 5 & Phoma sp. & $29-56$ & Aug. 2011 \\
\hline Brattleboro $^{\mathrm{g}}$ & 4 & Phoma sp. \& Myriangium sp. & $10-33$ & Sept. 2011 \\
\hline Amherst ${ }^{\mathrm{f}}$ & 5 & Phoma sp. & $20-58$ & Aug. 2011 \\
\hline Milford ${ }^{\mathrm{f}}$ & 5 & Phoma sp. & $30-60$ & Aug. 2011 \\
\hline Pelham ${ }^{\mathrm{f}}$ & 5 & $\begin{array}{c}\text { Myriangium sp. \& } \\
\text { Metarhiziopsis microspora }\end{array}$ & $23-55$ & Aug. 2011 \\
\hline Newmarket ${ }^{\mathrm{f}}$ & 5 & Phoma sp. \& Myriangium sp. & $20-56$ & Aug. 2011 \\
\hline Hudson ${ }^{\mathrm{f}}$ & 5 & Phoma sp. & $32-61$ & Aug. 2011 \\
\hline Berry Brook ${ }^{f}$ & 5 & Phoma sp. & $23-84$ & Aug. 2011 \\
\hline
\end{tabular}

a: New York State; b: Connecticut; c: Massachusetts; d: Pennsylvania; e: Maine; f: New Hampshire; g: Vermont. 
Figure 1. Elongate hemlock scale mycosis caused by Myriangium duriaei before (A) and after $(\mathbf{B})$ sclerotization. $($ Bars $=0.5 \mathrm{~mm})$

A

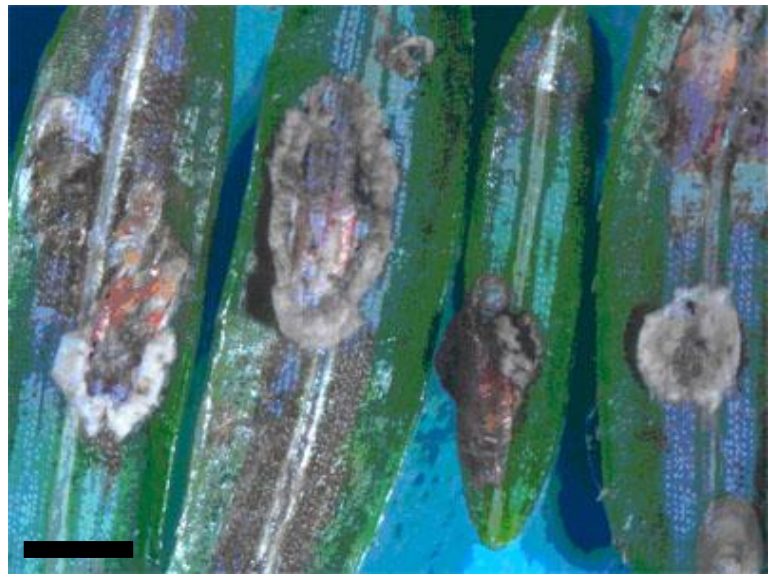

B

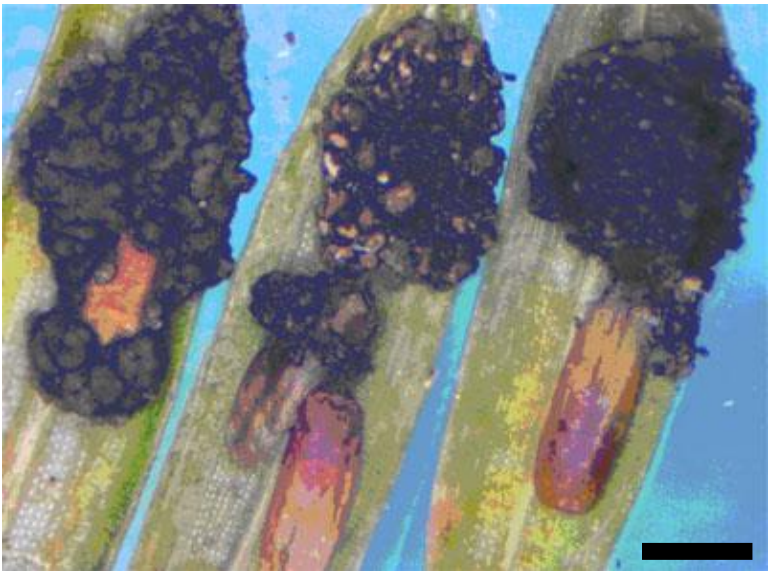

Figure 2. Myriangium duriaei in culture: mycelial mass (A), and formation of chlamydospores $(\mathbf{B})$; cotton blue stain, objective $\times 100$.

A

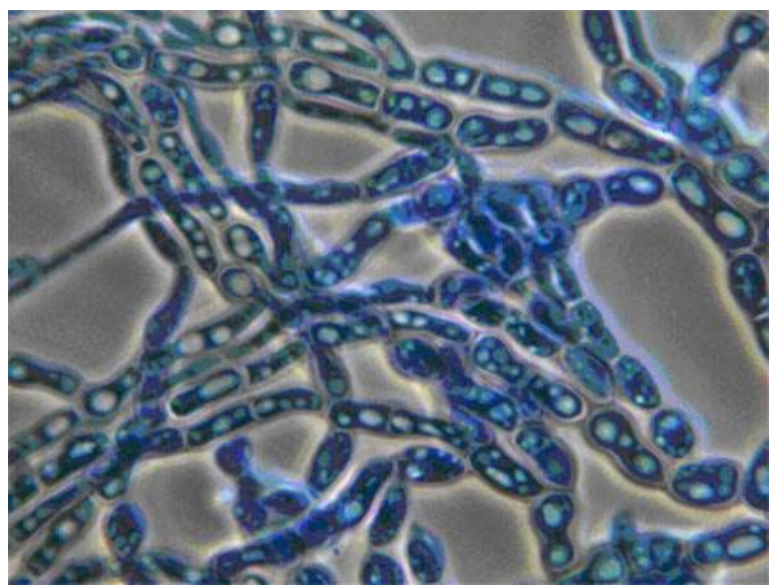

B

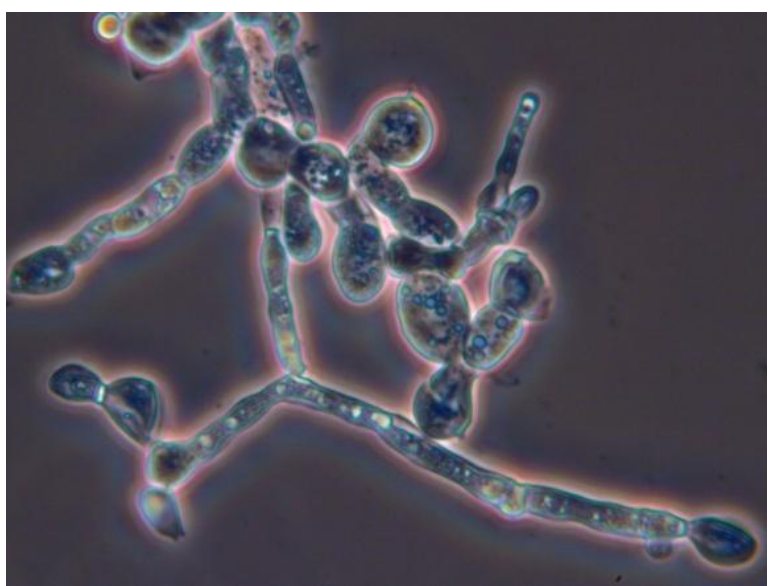

Figure 3. Elongate hemlock scale crawlers (a: 1st mobile instar) exiting from female body (b: outline of female body) containing sclerotia of Myriangium duriaei; phase contrast, objective $\times 10$. $($ Bar $=0.5 \mathrm{~mm})$

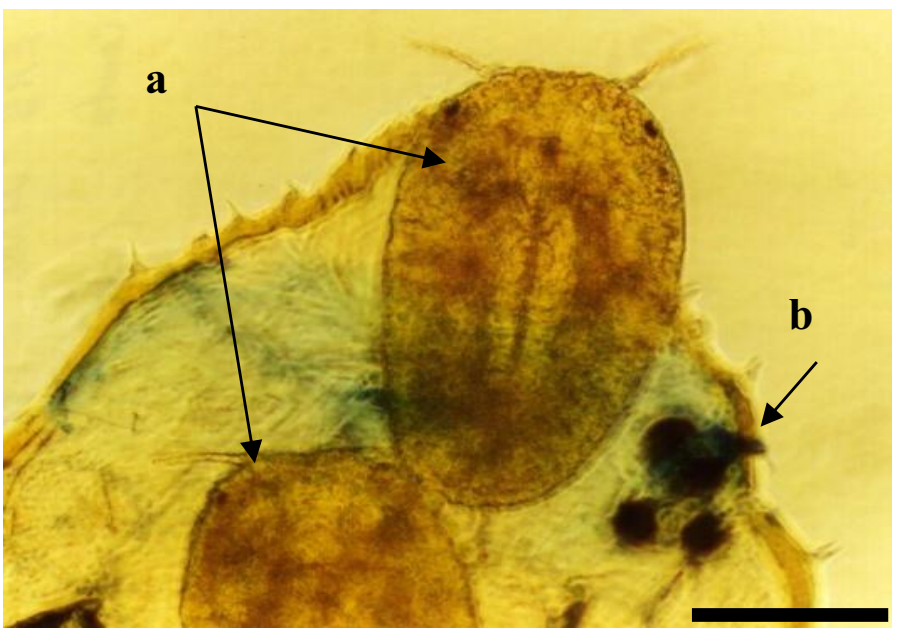


Figure 4. Elongate hemlock scale mycosis caused by the fungus Metarhiziopsis microspora: scales with sporodochia (A); mature conidia, cotton blue stain, objective $\times 100$ (B). $(\mathrm{Bar}=0.5 \mathrm{~mm})$

A

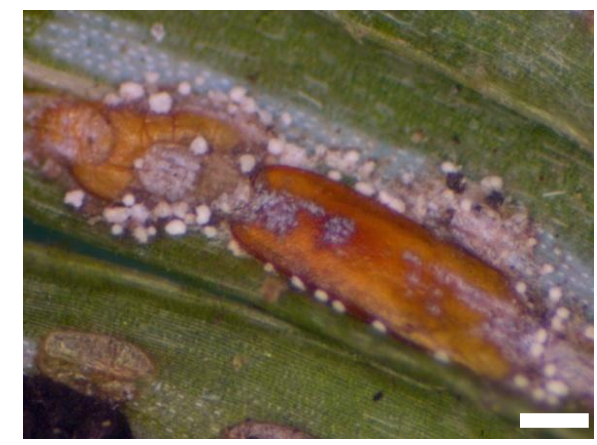

B

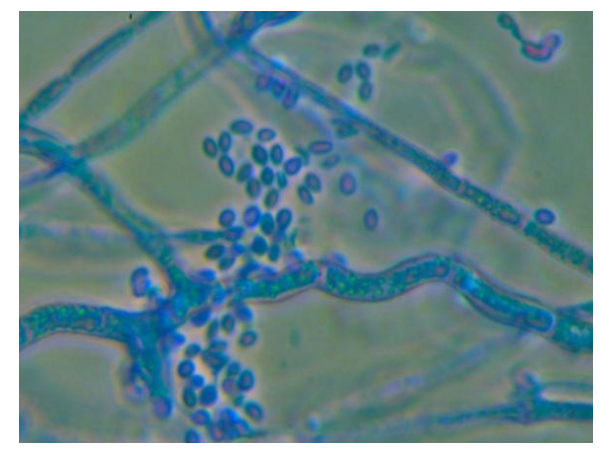

Both types of mycoses were recorded concurrently in EHS populations. Mortality of insects, including mature insects and immature settlers, caused by $M$. duriaei in association with $C$. fioriniae was $100 \%$ in the center of the epizootic. Scales with signs of the second type of mycosis occurred sporadically together with the entomopathogenic fungi, B. bassiana and Lecanicillium spp. Numerous facultative fungal isolates of hemlock woolly adelgid were identified as species from the genera Acremonium, Alternaria, Botrytis, Fusarium, Nectria, Rhinocladiella, and Scopulariopsis. Fungi in the genera Mucor, Penicillium sp., Aspergillus sp., and some others, were usually present as ubiquitous opportunistic contaminants. Bioassays indicated that $C$. fioriniae was highly pathogenic to elongate hemlock scale. Mortality rates of $>90 \%$ and $>55 \%$ were obtained for crawlers and settlers, respectively [35].

Mycological and pathological analyses of the lecanium scale (LS) were conducted in plant material collected at different forest stands of Vermont, showing a profuse number of scale insects. Most twigs sampled contained scales with specific signs of mycoses typical of entomopathogenic fungi in the genus Hirsutella. Insects with signs of mycoses were used for isolation of entomopathogenic fungi from which 20 isolates of Hirsutella lecaniicola were obtained. The fungus forms a specific coremia on the surface of infected LS hosts, and, as a result, this insect pathogen can be easily detected (Figure 5). In addition, several other entomopathogenic fungi were isolated from lecanium scale including, B. bassiana, L. muscarium, I. farinosa and phytopathogenic fungi from the genus Fusarium.

Figure 5. European fruit lecanium infected with the fungus Hirsutella lecaniicola (A); mature culture of fungus on nutrient medium, phase contrast, cotton blue stain, objective $\times 100(\mathbf{B})$. $(\mathrm{Bar}=0.5 \mathrm{~mm})$
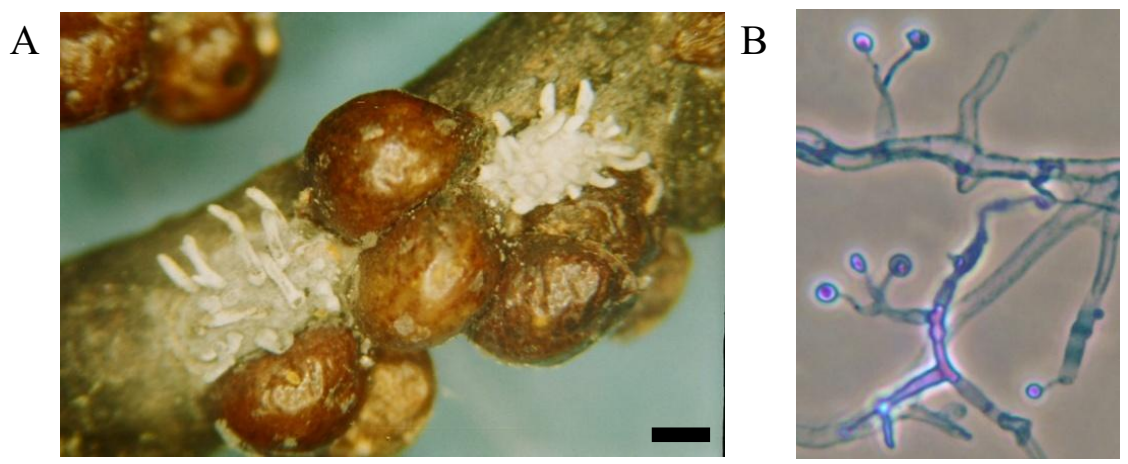
Fungi associated with hemlock woolly adelgid (HWA) were collected throughout the infestation area covering the northeastern region of the USA. Several hundred fungal colonies were isolated from 1996 to 2012 [10,11,32]. Isolates included B. bassiana and unidentified species from the genera Paecilomyces, Lecanicillium and Myriangium. A significant number of the isolates included entomophilous and phytopathogenic fungi in the genera Phoma, Fusarium, Cladosporium, Alternaria, Xylaria, Penicillium, Aspergillus, Mucor, Rhinocladiella, Exophiala, Scopulariopsis, Doratomyces (=Periconia, Stysanus, Cephalotrichum) and Diplocladiella. A high level of HWA mortality, with characteristic signs of mycoses (i.e., profuse mycelia on the surface of the insect), was recorded in areas around York, Maine and Harriman State Park, as well as New York state, from 2010-2012. Adult and immature infected HWA had a specific appearance described as a blackened cuticle and a flabby body surface, with woolly masses covering part of the mature females. The rate of infection gradually dropped as the season progressed and culminated in the death of the insect. Visual observations and examination of diseased and dead insects, using the methods described above, have not revealed a single agent causing fungal infection, but more commonly fungal propagules of numerous different species both on the body surfaces and in the body cavities. Commonly the insects were completely filled with mycelial masses and no other pathogenic structures. Often, mycelia formed clusters of deep melanization. A first subgroup of isolates from HWA formed gray colonies which eventually darkened. The colonies were relatively circular in appearance with umbonate elevations and undulate margins. Cultures produced a brown pigment which diffused into the medium and formed septate mycelial masses with a strong vacuolization. Mature cultures formed deeply melanized sclerotia. These cultures were preliminarily identified as Myriangium sp. This morphological identification was confirmed by DNA analysis [14]. Biocontrol research with Myriangium sp. is currently underway. Some of the adelgid cadavers from different geographical locations (Table 1) had a body surface covered with structures in the form of goblets filled with numerous spores (Figure 6). A detailed morphological analysis of these structures indicated that the fungus was related to the genus Phoma. Phoma sp. and Myriangium sp. have caused high mortality of HWA in 10-12 days in laboratory bioassays. Phoma aspidioticola has been reported to be an effective pathogen of the armored scale, Aspidiotus destructor, in India [37].

Figure 6. Pycnidia of the fungus Phoma sp. located on body of hemlock woolly adelgid, cotton blue stain, objective $\times 40$.

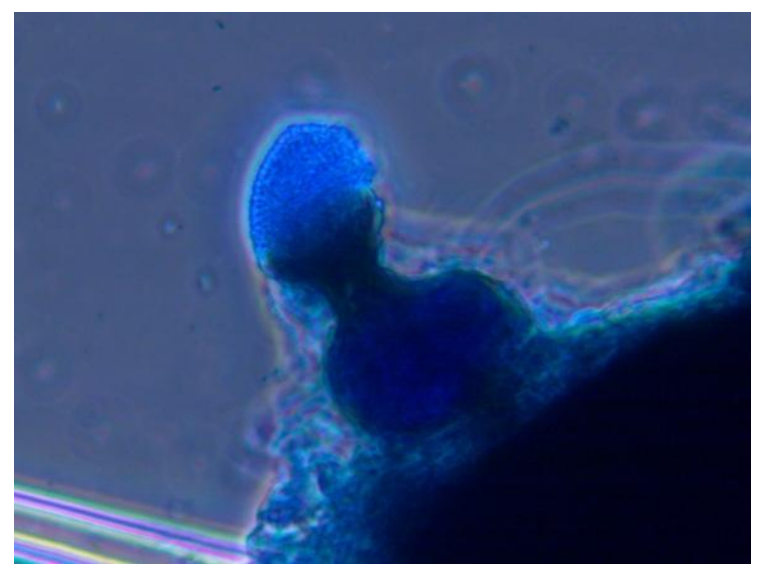


Myriangium sp. and Phoma sp. have different cultivation properties. The first is difficult to isolate in pure culture, because it grows slowly on different media, including PDA and SDAY, without production of any sexual morphological structures. Conversely, Phoma sp. grows quickly and forms specific fruiting structures. Based on the high rate of Phoma sp. recovered from infected populations of hemlock woolly adelgid, it is highly probable that the reason for the mass mortality of hemlock woolly adelgid is the activity of this pathogen. Together with the activity of Myriangium sp., Phoma sp. is therefore very likely to be involved in the epizootiological process affecting adelgids, however, currently the mechanism of infection and etiology of this disease is unknown.

Damage caused by pear thrips has fluctuated from year to year. However, since outbreaks in 1985-1988, the population density has not been severe, and the activity of entomopathogenic fungi may be one of the reasons. Pear thrips remain in the soil for 10 mo of the, from mid-June to mid-April and entomopathogenic hyphomycetous fungi are closely associated with soil. Entomopathogenic fungi are known as important natural enemies of soil-dwelling arthropods [9,38]. A complex of entomopathogenic fungi has been reported to cause significant pear thrips mortality in forest litter and in the upper soil substrata [39]. We identified the fungi associated with pear thrips and other common soil arthropods such as fungal gnats, collembolans and mites (Table 2). A total of 1104 arthropods and 325 pear thrips were analyzed for mycological pathogens. A large portion of the arthropods were contaminated by fungi. The following genera were commonly isolated: Aspergillus, Beauveria, Cladosporium Conidiobolus, Fusarium, Isaria, Lecanicillium, Mariannaea, Metarhizium, Mucor, Paecilomyces, Penicillium, Rhinocladiella, and Trichoderma. The distribution of pear thrips within populations from different localities is listed in Table 2. Fungi in the genus Lecanicillium significantly prevailed in comparison with other fungi. The infection level of thrips with Lecanicillium fluctuated from $12.5 \%-51 \%$ in Vermont, $44.7 \%-45.4 \%$ in New Hampshire and $>50 \%$ in New York. The overall level of infection of pear thrips by entomopathogenic fungi ranged from $58.1 \%-87.5 \%$ in Vermont, $68.2 \%-68.4 \%$ in New Hampshire, and $83 \%-100 \%$ in New York. For Vermont, the most commonly isolated fungi were in the genera Lecanicillium followed by those in the genera Beauveria, Metarhizium, Isaria and Mariannaea. Samples from New York contained a small number of pear thrips infected with Lecanicillium spp. and Isaria spp. (Table 2). The rate of fungal infection among other arthropods with Lecanicillium spp. fluctuated between $22.8 \%-50 \%$ in Vermont, $16.1 \%-50.5 \%$ in New Hampshire and $11.4 \%-25.45 \%$ in New York. Fungi from the genus Lecanicillium appeared to be an important limiting factor of pear thrips population growth [1,10,39]. Pathogen loads in thrips populations could be used to monitor their health and provide a rapid and perhaps accurate assessment of the ecological status of this pest.

From our research with entomopathogenic fungi in northeastern forests $>200$ isolates in the genera Beauveria, Lecanicillium, Metarhizium, Isaria, Paecilomyces, Mariannaea, Hirsutella, Fusarium and Rhinocladiella were deposited in the USDA-ARS Collection of Entomopathogenic Fungal Cultures and the Collection of Microorganisms Useful for Plant Protection at the Entomology Research Laboratory (University of Vermont, Burlington, VT, USA). Fungal cultures were divided into three groups: (a) specialized entomopathogenic species, Mariannaea sp. Myriangium duriaei Mont. \& Berk., Myriangium sp., Hirsutella lecaniicola (Jaap) Petch, Hirsutella sp., Metarhiziopsis microspora, Beauveria bassiana (Balsamo-Crivelli) Vuillemin, Lecanicillium muscarium (Petch) Zare \& W Gams, L. psalliotae (Treschow) Zare \& Gams, Lecanicillum sp. Paecilomyces marquandii (Massee) Hughes, 
Isaria farinosa (Holmsk.) Fries, Isaria sp. and Colletotrichum fioriniae (Marcelino \& Gouli) R.G. Shivas \& Y.P.; (b) facultative entomopathogens, Rhinocladiella sp., Nectria sp., Botrytis sp., Fusarium sp., Phyalophora sp., Phoma sp.; (c) ubiquitous opportunistic contaminants, Penicillium sp., Cladosporium sp., Scopulariopsis sp., and Aspergillus sp.

Table 2. Entomopathogenic and entomophilous fungi isolated from pear thrips and associated soil arthropods (mites, collembolans and fungus gnats) on forest soil during the period of August-October 2011.

\begin{tabular}{|c|c|c|c|c|c|c|c|c|c|c|c|c|}
\hline \multirow{3}{*}{ Sample sites } & \multicolumn{2}{|c|}{$\begin{array}{c}\text { Number of } \\
\text { sampled } \\
\text { arthropods }\end{array}$} & \multicolumn{10}{|c|}{ Number of arthropods infected with entomopathogenic fungi } \\
\hline & \multirow[t]{2}{*}{ Thrips } & \multirow[t]{2}{*}{ Others } & \multicolumn{2}{|c|}{$\begin{array}{c}\text { Lecanicillium } \\
\text { spp. }\end{array}$} & \multicolumn{2}{|c|}{$\begin{array}{c}\text { Beauveria } \\
\text { bassiana }\end{array}$} & \multicolumn{2}{|c|}{$\begin{array}{c}\text { Metarhizium } \\
\text { anisopliae }\end{array}$} & \multicolumn{2}{|c|}{ Isaria spp. } & \multicolumn{2}{|c|}{$\begin{array}{l}\text { Mariannaea } \\
\text { spp. }\end{array}$} \\
\hline & & & Thrips & Others & Thrip & Other & Thrips & Other & Thrip & Other & Thrip & Other \\
\hline Bakersfield $^{\text {a }}$ & 44 & 76 & 16 & 31 & 4 & 4 & 3 & 2 & 2 & 7 & 0 & 0 \\
\hline Richford $^{\text {a }}$ & 8 & 88 & 3 & 25 & 0 & 5 & 0 & 0 & 3 & 5 & 1 & 1 \\
\hline Derby $^{a}$ & 8 & 20 & 1 & 8 & 2 & 2 & 0 & 0 & 7 & 23 & 1 & 0 \\
\hline Randolph $^{\text {a }}$ & 47 & 79 & 24 & 18 & 2 & 0 & 0 & 0 & 7 & 5 & 1 & 1 \\
\hline Underhill $^{\text {a }}$ & 14 & 331 & 57 & 130 & 5 & 3 & 2 & 2 & 18 & 3 & 0 & 0 \\
\hline Westfield $^{\text {a }}$ & 4 & 40 & 1 & 20 & 1 & 1 & 0 & 0 & 0 & 7 & 0 & 0 \\
\hline Altona $^{\mathrm{b}}$ & 4 & 71 & 0 & 14 & 0 & 0 & 0 & 0 & 3 & 7 & 0 & 0 \\
\hline Rupert ${ }^{\text {b }}$ & 6 & 110 & 2 & 28 & 0 & 5 & 0 & 0 & 2 & 23 & 1 & 1 \\
\hline $\begin{array}{l}\text { Sharon } \\
\text { Springs }{ }^{b}\end{array}$ & 3 & 88 & 1 & 10 & 0 & 3 & 0 & 0 & 2 & 5 & 0 & 0 \\
\hline Langdon $^{c}$ & 22 & 130 & 10 & 21 & 0 & 0 & 0 & 0 & 2 & 5 & 3 & 3 \\
\hline Oxford $^{\mathrm{c}}$ & 38 & 91 & 17 & 46 & 5 & 3 & 0 & 0 & 3 & 3 & 1 & 1 \\
\hline
\end{tabular}

a: Vermont; b: New York State; c: New Hampshire state.

\section{Conclusions}

Based on the data reported herein, we conclude that many arthropods in forest soil are infected with different species of entomopathogenic and entomophilous fungi. It is hypothesized that the isolated fungi found play a significant role as biotic factors regulating arthropod populations. Most of the fungi recovered in the forest were ecologically associated with the soil and thus had a limited capability for persisting in the tree canopy, where populations of insect pests may reside. Therefore, a single application of B. bassiana and L. muscarium, isolated from soil-dwelling insects, may not provide long-term suppression of pests in the tree canopy. Insect populations were able to re-establish after the winter, as previously observed following chemical treatments. However, this research indicates that use of entomopathogenic fungi, as an alternative biocontrol strategy to counteract the economic impact of pests in northeastern forests, is able to generate mortality rates identical or superior to those from agricultural chemicals without the associated costs and long-term deleterious impacts in the environment. Additional research is needed to develop the full potential of entomopathogenic fungi for integrated pest management in forests. 


\section{Acknowledgments}

This research was supported, in part, by the USDA Forest Service (Projects: \#05-CA-11244225-137 and \#04-CA-11244225-286), USDA Agricultural Research Service (Project \#58-1907-55-21), Vermont Maple Sugar Makers' Association, Northeastern Maple Syrup Producers Association and the Northeastern States Research Cooperative (Project \# 11-DG-11242307-047). We are grateful to all individuals connected with the protection of forests, who have provided us with their assistance with collecting samples and locating suitable test sites. The authors would also like to thank the valuable suggestions of two anonymous reviewers.

\section{Conflicts of Interest}

The authors declare no conflict of interest.

\section{References and Notes}

1. Parker, B.L. The pear thrips problem. In Towards Understanding Thysanoptera. Gen. Tech. Rep. NE-147; Parker, B.L., Skinner, M., Lewis, T., Eds.; US Department of Agriculture, Forest Service, Northeastern Forest Experimental Station: Newtown Square, PA, USA, 1991; pp. 179-192.

2. Teillon, H.B.; Burns, B.S.; Kelley, R.S. Forest Insect and Disease Conditions in Vermont, Calendar Years 1985-1988; Vermont Agency of Natural Resources, Department of Forests, Parks and Recreation: Waterbury, VT, USA, 1988; pp. 1-147.

3. Skinner, M.; Parker, B.L. Bioecology of pear thrips: Distribution in forest soils. In Towards Understanding Thysanoptera; Parker, B.L., Skinner, M., Lewis, T., Eds.; US Department of Agriculture, Forest Service: Newtown Square, PA, USA, 1991; pp. 193-211.

4. Smith, G.; Petersen, C.M.; van Driesche, R.; Burnham, C. The relationship between measures of tree vigor and pear thrips damage in sugar maple. In Towards Understanding Thysanoptera Gen. Tech. Rep. NE-147; Parker, B.L., Skinner, M., Lewis, T., Eds.; US Department of Agriculture, Forest Service, Northeastern Forest Experimental Station: Newtown Square, PA, USA, 1991; pp. 273-284.

5. Parker, B.L.; Skinner, M.; Teillon, H.B. The 1988 thrips infestation of sugar maple. In Proceedings of the Regional Meeting, Burlington, VT, USA, 23 June 1988; pp. 1-133.

6. McClure, M.S.; Cheah, A.S.-J. Important mortality factors in the life cycle of hemlock woolly adelgid, Adelges tsugae Annand (Homoptera: Adelgidae) in the Northeastern United States. In Proceedings of the Symposium on the Hemlock Woolly Adelgid in Eastern North America Meeting, East Brunswick, NJ, USA, 2002; pp. 13-33.

7. Salom, S.M.; Kok, L.T.; Lamb, A.; Jubb, C.; Onken, B. Biological control of hemlock woolly adelgid: What is going to take to make it work? In Proceedings of the Fourth Symposium on Hemlock woolly adelgid in the Eastern United States Meeting, Hartford, CT, USA, 2008; pp. 11-17.

8. Cheah, C.A.S.-J.; Montgomery, M.E.; Salom, S.; Parker, B.L.; Costa, S.; Skinner, M. Biological Control of Hemlock Woolly Adelgid; USDA Forest Service: Morgantown, WV, USA, 2004. 
9. Brownbridge, M.; Humber, R.A.; Parker, B.L.; Skinner, M. Fungal entomopathogens recovered from Vermont forest soil. Mycology 1993, 85, 358-361.

10. Gouli, V.V.; Gouli, S.; Parker, B.L.; Skinner, M. Fungi as epizootic factor in populations of sucking alien insects in northeastern region of the USA. In Proceedings of the International Conference for IPM: Strategy and Tactics Meeting, Minsk, Belarus, 2011; pp. 206-211.

11. Gouli, S.Y.; Parker, B.L.; Skinner, M. Isolation of fungi associated with hemlock woolly adelgid (Homoptera: Adelgidae). J. Invertebr. Pathol. 1997, 70, 76-77.

12. Gouli, S.; Gouli, V.V.; Teillon, H.B.; Kassa, A.; Skinner, M.; Frank, C.; Parker, B.L. Controlling hemlock woolly adelgid with new forms of mycoinsecticides. In Proceedings of the Fourth Symposium on Hemlock Woolly Adelgid in the Eastern United States Meeting, Hartford, CT, USA, 2008; pp. 179-187.

13. Marcelino, J.A.P.; Giordano, R.; Gouli, S.; Gouli, V.; Parker, B.L.; Skinner, M.; TeBeest, D.; Cesnik, R. Colletotrichum acutatum var. fioriniae (teleomorph: Glomerella acutata var. fioriniae var. nov.) infection of a scale insect. Mycologia 2008, 100, 353-374.

14. Marcelino, J.A.P.; Gouli, S.; Giordano, R.; Gouli, V.V.; Parker, B.L.; Skinner, M. Fungi associated with a natural epizootic in Fiorinia externa Ferris (Hemiptera: Diaspididae) populations. J. Appl. Entomol. 2009, 133, 82-89.

15. Hajek, A.E. Pathology and epizootiology of Entomophaga maimaiga infections in forest Lepidoptera. Microbiol. Mol. Biol. Rev. 1999, 63, 814-835.

16. Hajek, A.E.; McManus, M.L.; Delalibera, I. A review of introductions of pathogens and nematodes for classical biological control of insects and mites. Biol. Control 2007, 41, 1-13.

17. Keller, S. Arthropod-pathogenic Entomophthorales of Switzerland II. Erynia, Eryniopsis, Neozygites, Zoophthora and Tarichium. Sydowia 1991, 44, 118-146.

18. Balazy, S. Fungi (Mycota), Entomophthorales. In Flora of Poland; Polish Academy of Sciences: Krakow, Poland, 1993.

19. Delalibera, I.; Hajek, A.E.; Humber, R.A. Neozygites tanajoae sp. nov., a pathogen of the cassava green mite. Mycologia 2004, 96, 1002-1009.

20. MacLeod, D.M.; Tyrrell, D.; Soper, R.S. Entomophthora canadiensis n.sp., a fungus pathogenic on the woolly pine needle aphid, Schizolachnus piniradiatae. Can. J. Bot. 1979, 57, 2663-2672.

21. Voronina, E.G.; Lednev, G.R.; Mukamolova, T.Y. Entomophthoralean fungi. In Insect Pathogens: Structural and Functional Aspects; Krugli God: Moscow, Russia, 2001; pp. 271-351.

22. Barta, M. Entomophthoralean fungi associated with aphid in woody plants in the Arboretum Mlynany SAS. Folia Oecol. 2009, 36, 1-7.

23. Humber, R.A. Collection of Entomopathogenic Fungal Cultures; USDA Agriculture Research Service: Ithaca, NY, USA, 2011; pp. 1-508.

24. Gouli, V.V.; Rybina, S.Y. Viral Diseases and Their Diagnostics; Chisinau Institute: Chisinau, Moldova, 1988.

25. Gouli, V.V.; Provost, C.; Parker, B.L.; Skinner, M.; Gouli, S. Comparison of two methods for estimation of spray deposits after application of microbial pesticides. Biocontrol. Sci. Technol. 2010, 20, 331-337.

26. Schmitthenner, A.F.; Hilty, J.W. A modified dilution technique for obtaining single-spore isolates of fungi from contaminated material. Phytopathology 1962, 52, 582-583. 
27. Evlachova, A.A. Entomopathogenic Fungi (in Russian); Nauka: Leningrad, Russia, 1974.

28. Koval, E.Z. Key of Entomophilous Fungi of USSR; Naukova Dumka: Kiev, Ukrain, 1974; pp. 1-257.

29. Samson, R.A.; Evans, H.C.; Latge, J.-P. Atlas of Entomopathogenic Fungi; Springer-Verlag: Berlin, Germany, 1988; pp. 1-187.

30. Humber, R.A. Fungi: Identification. In Manual of Techniques in Insect Pathology; Academic Press: New York, NY, USA, 1997; pp. 153-185.

31. Skinner, M.; Gouli, V.V.; Gouli, S.; Marcelino, J.A.P.; Parker, B.L. Entomopathogenic fungi for management of invasive armored scales in northeastern forests. In Proceedings of the Fourth Symposium on Hemlock Woolly Adelgid in the Eastern United States Meeting, Hartford, CT, USA, 2008; pp. 193-202.

32. Reid, W.R.; Parker, B.L.; Gouli, S.Y.; Skinner, M.; Gouli, V.V.; Teillon, H.B. Fungi associated with Adelges. tsugae, and assessment of entomopathogenic isolates for hemlock woolly adelgid management. J. Insect Sci. 2010, 62, 1-18.

33. McClure, M.S.; Salom, S.M.; Shields, K.S. Hemlock Woolly Adelgid; USDA Forest Service FHTET-2001-2003: Morgantown, WV, USA, 2003; pp. 1-14.

34. Shivas, R.G.; Tan, Y.P. A taxonomic re-assessment of Colletotrichum acutatum, introducing C. fioriniae comb. et stat. nov and C. simmondsii sp. nov. Fungal Divers. 2009, 39, 111-122.

35. Marcelino, J.A.P.; Gouli, S.; Parker, B.L.; Skinner, M.; Giordano, R. Entomopathogenic activity of a variety of the fungus Colletotrichum acutatum, recovered from the elongate hemlock scale, Fiorinia externa. J. Insect Sci. 2009, 9, 1-13.

36. De-Wei, L.; Cowles, R.S.; Vossbrinck, C.R. Metarhiziopsis microspora gen. et sp. nov. associated with elongate hemlock scale. Mycology 2008, 100, 460-466.

37. Narendra, D.V.; Rao, V.G. A new entomogenous species of Phoma Mycopathol. Mycol. Appl. 1974, 54, 135-140.

38. Parker, B.L.; Skinner, M.; Costa, S.D.; Gouli, S.; Reid, W.; El Bouhssini, M. Entomopathogenic fungi of Eurygaster. integriceps Puton (Hemiptera: Scutelleridae): Collection and characterization for development. Biol. Control 2003, 27, 260-272.

39. Skinner, M.; Parker, B.L.; Bergdahl, D.R. Verticillium lecanii isolated from larvae of pear thrips, Taeniothrips. inconsequens, in Vermont. J. Invertebr. Pathol. 1991, 58, 157-163.

(C) 2013 by the authors; licensee MDPI, Basel, Switzerland. This article is an open access article distributed under the terms and conditions of the Creative Commons Attribution license (http://creativecommons.org/licenses/by/3.0/). 